\title{
METHODOLOGY OF RESEARCH IN SPORTS SOCIOLOGY
}

\author{
J. SHUTTLEWORTH
}

\author{
Liverpool Polytechnic
}

The dearth of research into sport by sociologists can be attributed in the U.K. to two main factors.

Firstly, sport is considered by many sociologists to be ancillary to such institutions within the social system as education, the family, the mass media and more particularly the social and political systems. The centrality of socio-political and economic research is a result of the issues associated with man's function within contemporary industrialized society. The limited amount of research conducted has been of microsocial systems rather than macrosocial systems thus isolating it from mainstream sociological thinking.

Secondly, with the increasing awareness by sociologists of their social responsibilities, there has been a deliberate policy adopted of utilitarian and applied research oriented towards salient social problems. This approach ignores social organisations and processes that are not deviant or dysfunctional and within this context, investigation into sport has been oriented to such phenomena as soccer violence, apartheid and sport's remedial function in areas of urban malaise. Sport thus receives attention only when, as a function of work, it conflicts with institutionalised means of fulfilment. This approach fails to appreciate the essential role of physical activity in the attainment of man's self-actualisation and the development of his imagination and has precluded much rewarding research into the social structure, function and processes of organisations concerned with sport.

The small amount of research into sports sociology that has actually been attempted has been constrained by the overall methodology employed. For instance, a review of research conducted under the rubric of sports sociology by Crandall and Lewko (1976) and Loy and Segrave (1975), indicates that the majority of investigations were concerned with the social attributes and behavioural dispositions of the participants in sport, research which could more appropriately be ascribed to psychology or social psychology. Sports sociology as a sub-set of mainstream sociology, should show greater concern for the macrosocial system analysis of sports organisations and social processes rather than concentrating upon the interactions and motivations of individuals.

A further limitation has been the preoccupation with quantitative empirical research which Wohl (1975) and Ventris (1975) contend has been conducted without due regard to the causal chain and the construction of theo- retical paradigms. Such an experimental process has brought about the divorce of theoretical constructs from empirical research with the resultant pursuit of peripheral topics rather than more essential issues in sport's milieu.

The implications for sports sociology research engendered by this critique are threefold. Firstly, when evolving research strategy at the intermediate or macro levels of analysis, the most viable means of deriving valid theories is to conceive of sport holistically in terms of sport systems which are a function of the social matrix of which they are a part. Secondly, an attempt should be made to formulate a theoretical model incorporating an entire sports system causal chain pursuant upon the formulation of deductive theories based upon the rigorous appraisal of the appropriate research. This model should be susceptible to empirical investigation thereby merging formal theory and empirical observation more readily than does the prevailing quantitative and descriptive approach. Thirdly, the empirical validation of such theoretical paradigms of sport should employ the case study approach together with more sophisticated data processing methods such as qualitative coding, factor analysis and principle component analysis. McPherson (1972) has pioneered this type of research in $N$. America but attempts in the U.K. have been limited to Levy (1974), Maw (1969) and Shuttleworth (1975) who have all devised leisure models capable of validation.

In summary it may be stated that there is a need for sports sociologists, particularly in the U.K., to show a greater commitment to theoretical construction at the macrosocial level. An increased use of sports and social systems models such as those devised by Allardt (1967) and Glassford (1967) together with more sophisticated statistical techniques will facilitate the generation of sports theories and thus an approach to more effective planning, management and coaching in sports. Secondly, a greater emphasis upon social processes in an interdisciplinary context is called for. For instance, little is known about the socialisation process by which people become sports consumers. Finally, it is felt that sport sociologists should assume the role of agents of change. A radical critique of contemporary sport in the U.K., similar to that provided by Scott (1971) in American Sport, is long overdue. By these means sports sociology will reorientate itself away from the oversocialised and functional pursuit of peripheral topics and face the salient issues of sport today. 


\section{BIBLIOGRAPHY}

Allardt, E. (1967) "Basic Approaches in Comparative Sociological Research and the Study of Sport", The CrossCultural Analysis of Sport and Games. ed. G. Luschen, Illinois: Stipes Publishing Co.

Crandall, R. and J. Lewko (1976) "Leisure Research, Present and Future: Who, What, Where"; Journal of Leisure Research. Vol. 8, No. 3, 1976.

Glassford, G. (1967) "Organisation of Games and Adaptive Strategies of the Canadian Eskimo". The Cross-Cultural Analysis of Sport and Games. ed. G. Luschen, Illinois: Stipes Publishing Co.

Levy, J. (1974) "An Applied Intersystem Congruence Model of Play, Recreation and Leisure". Human Factors. 15.5.

Loy, J. and J. Segrave (1975) "Research Methodology in the Sociology of Sport", Exercise and Sport Sciences Reviews. ed. J. Wilmore, N.Y.: Academic Press.

Maw, R. (1969) "Construction of a Leisure Model", Official Architecture and Planning. (August, 1969).

Scott, J. (1971) The Athletic Revolution. N.Y.: The Free Press.

Shuttleworth, J. (1975) Community Education and Recreation in England and Wales: The Derivation of a General Approach. Unpublished Ph.D. Thesis, University of Alberta.

Ventris, N. (1975) Some Problems in the Use of Survey Results for Recreational Planning. Unpublished paper presented at the symposium on Work and Leisure, Polytechnic of Central London.

Wohl, A. (1975) "Some Remarks on the Methodology of Research on the Sociology of Sport", International Review of Sports Sociology. 2 (10). 